Volume 3

Issue 1 The Syriac Galen Palimpsest

Article 10

5-9-2019

\title{
Preserving Endangered Archives in Jerba, Tunisia: The al-Bāsī Family Library Pilot Project
}

Ali Boujdidi

University of Gabès, Médenine, ali.boujdidi@gmail.com

Paul Love

Al Akhawayn University, p.love@aui.ma 


\title{
Preserving Endangered Archives in Jerba, Tunisia: The al-Bāsī Family Library Pilot Project
}

\begin{abstract}
In July 2017, we launched a project entitled "Preserving Endangered Archives in Jerba, Tunisia: The al- Bāsī Family Library Pilot Project." 1 Generously supported by the Endangered Archives Programme (EAP) funded by the British Library and Arcadia, the project aims at the digital preservation of the private Arabic manuscript library of the al- Bāsī family in the town of Houmet Souk on the island of Jerba in southern Tunisia. This report offers a brief history of the collection and its contents as well as a description of the project's training efforts and aims.
\end{abstract}

\section{Keywords}

Endangered Archives, al-Bāsī Family Library, digital preservation, Arabic manuscripts, Tunisia 


\section{MANUSCRIPT STUDIES}

A Journal of the Schoenberg Institute for Manuscript Studies

VOLUME 3, NUMBER 1

(Spring 2018)

Manuscript Studies (ISSN 2381-5329) is published semiannually

by the University of Pennsylvania Press

The Schoenberg Institute
for Manuscript Studies
University of Pennsylvania Libraries 


\title{
MANUSCRIPT STUDIES
}

A Journal of the Schoenberg Institute for Manuscript Studies

VOLUME 3, N UMBER 1

\author{
Special Issue: \\ The Syriac Galen Palimpsest \\ Editors: William Noel and Ralph M. Rosen
}

\section{Articles}

The Syriac Galen Palimpsest Project: An Introduction

William Noel and Ralph M. Rosen

Pulling It All Together: Managing the Syriac Galen

Palimpsest Project

Michael B. Toth

The Codicology and Conservation of the Syriac

Galen Palimpsest

Abigail B. Quandt and Renée C. Wolcott

Spectral Imaging Methods Applied to the Syriac

Galen Palimpsest

Roger L. Easton, Jr., Keith T. Knox, William A. Christens-Barry, And Ken Boydston

The Galen Palimpsest and the Modest Ambitions of the

Digital Data Set

Doug EMERY

The Syriac Galen Palimpsest: A Tale of Two Texts

Naima Afif, Siam Bhayro, Grigory Kessel, Peter E. Pormann,

William I. Sellers, and Natalia Smelova 
iv | Journal for Manuscript Studies

Analyzing Images, Editing Texts: The Manchester Project

Naima Afif, Siam Bhayro, Peter E. Pormann, William I. Sellers,

and Natalia Smelova

The Textual Interest of the Syriac Versions of Galen's Simples

Irene Calà, Jimmy Daccache, and Robert Hawley

\section{Annotations}

Of Scribes and Scripts: Citizen Science and the Cairo Geniza

Laura Newman Eckstein

Preserving Endangered Archives in Jerba, Tunisia:

The al-Bāsī Family Library Pilot Project

Ali Boujdidi And Paul M. Love

The Intricacies of Capturing the Holdings of a Mosque

Library in Yemen: The Library of the Shrine of Imām alHādī, Șa da

Sabine Schmidtke

Compilation, Collation and Correction in the Time of Encyclopedism: The Case of UPenn LJS 55

Nathalie Lacarrière

Mapping Manuscript Migrations: Digging into Data for the

History and Provenance of Medieval and Renaissance

Manuscripts

Toby Burrows, Eero Hyvönen, Lynn Ransom, and Hanno Wijsman

\section{Reviews}

Ahmad 'Abd al-Bāsiṭ. Catalogue of the Private Collections of

Manuscripts in the Egyptian National Library

ELIAS G. SABA 
David T. Gura. A Descriptive Catalogue of the Medieval and Renaissance Manuscripts of the University of Notre Dame and Saint Mary's College

Lisa Fagin Davis

Christopher De Hamel. Meetings with

Remarkable Manuscripts

Daniel Traister 
Boujdidi and Love: Preserving Endangered Archives in Jerba, Tunisia: The al-B?s? Fam 


\title{
Preserving Endangered Archives in Jerba, Tunisia \\ The al-Bāsī Family Library Pilot Project
}

\author{
Ali Boujdidi \\ University of Gabès, Médenine \\ Paul M. Love \\ Al Akhawayn University
}

I

N July 2017, we launched a project entitled "Preserving Endangered Archives in Jerba, Tunisia: The al-Bāsī Family Library Pilot Project." Generously supported by the Endangered Archives Programme (EAP) funded by the British Library and Arcadia, ${ }^{2}$ the project aims at the digital preservation of the private Arabic manuscript library of the al-Bāsì (fr. El Bessi) family in the town of Houmet Souk on the island of Jerba in southern Tunisia. This report offers a brief history of the collection and its contents as well as a description of the project's training efforts and aims.

\section{History of the al-Bāsī Manuscript Library}

The al-Bāsī library originated as the madrasa (religious school) of the al-Bāsī mosque, an Ibadi mosque in the district of Wâligh on the island of Jerba,

1 For project details, see http://eap.bl.uk/database/overview_project.a4d?projID=EAP 993;r=41.

2 Details on the Endangered Archives Programme are available at http://eap.bl.uk, accessed 27 July 2017. 
Tunisia. It is named after a family of traders active from the eighteenth to the early twentieth centuries with commercial ties to the Muslim east. The construction of the mosque lasted from 27 Ramadàn 1198 (23 July 1784 CE) to the end of Rabī' al-Thānī 1199 (February/March $1785 \mathrm{CE}$ ). The foundation of the mosque's library and the flourishing of its madrasa were the work of three brothers: Muḥammad, Sālim, and 'Uthmān, the sons of Hāajj Yahyaā al-Bāsī. According to an official endowment statement, the family endowed all books in the library as

an eternal endowment (habasan mu'abbadan) to the al-Bāsī Mosque for as long as they exist. They are neither to be sold nor exchanged. ... Visitors will not be denied access to them ... in the aforementioned dome during the time when the Shaykh is teaching. If the Shaykh leaves and the students disperse, [the books] will be left in their place. Whosoever violates this [rule] will be held accountable by God and revenge will be taken upon him-for He knows the transgressors!

Based on the original inventory list compiled by Haajj Sālim al-Bāsī (d. 1810), the library contained some 235 manuscript volumes, which were endowed to the mosque and its students. However, according to the second inventory compiled by Salìm al-Bāsī (d. 2011) in the late twentieth century, only about 170 titles remained. This amounts to a loss of some sixty-five titles.

Describing the library in his book on Arabic manuscript collections, Philippe de Tarrazi (d. 1956) wrote:

This Shaykh [Hājj Sālim] endowed for the students of knowledge many printed and manuscript books, which he stored in the library of the mosque attributed to him on the island of Jerba. In this library there are Quran manuscripts in elegant script, including one in which the exegesis [tafsir $]$ has been written below each verse in Turkish. The library is also distinguished by its books belonging to the Ibadi school [of Islam], including [works of] history, promi- 
nent scholars, literary figures, and poets who belong to this school. $^{3}$

Shaykh Sālim al-Bāsī, the founder of the library, had a long-term vision for the madrasa and an ambition to secure its reputation in the future. Thanks to this vision, the madrasa remained in operation for nearly a century and a half, from 1782 to 1927. Moreover, the al-Bāsī mosque continued its activities despite the changes to the political and economic landscapes in Djerba. When the endowment system in Tunisia began its decline, the mosque encountered numerous challenges.

The mosque remained open through the period of the French Protectorate (1881-1956) and into the era of independence (1956-present). However, mosque-based education was gradually replaced by that offered by secular schools. The manuscripts were removed from the mosque in the early 1980s by members of the El Bessi family. They describe its condition at the time as having been in complete disarray. After the manuscripts were relocated to the family estate in the city of Houmet Souk, the collection's owner, Salīm al-Bāsī (d. 2011), spent years reorganizing quires and drawing up the new inventory.

\section{Project Aims and Training Efforts}

At its core, the project aims to produce high-quality digital reproductions of the library's bound and unbound manuscript items for free use by researchers worldwide. Following the conclusion of the project, all photographs will be hosted on the British Library's Endangered Archives website. In addition to photographing the collection, however, the project likewise hopes to achieve several related objectives.

From the beginning, we hoped to offer training and resources to local students and researchers. We hosted a three-day intensive workshop on codicology and manuscript studies for our project team of six recent university

3 Philippe de Tarrazi, Khizā’in al-kutub al-'arabiyya fī l-kbāfiqayn (Beirut, n.d.), 361-62. 
graduates and other local participants who are responsible for photographing and documenting the collection. Training was in the town of Houmet Souk at the Association d'animation culturelle à Djerba from 24 to 26 July 2017. The sessions, led by the project coordinators Paul Love (Al Akhawayn University) and Ali Boujdidi (University of Gabès, Médenine), included a series of lectures on the history of the al-Bāsī mosque, an introduction to codicology and its terminology, and the importance of watermarks for the study of manuscripts. These lectures were complemented by a series of intensive, hands-on workshops that introduced the team to preparing manuscript descriptions, photographing the manuscripts according to the standards outlined by the EAP, the description and photographing of watermarks, and the archiving and indexing of images.

We will also be working closely with the El Bessi family to ensure that the collection is stored in the appropriate environment when returned to their residence after the project ends. This will include monitoring the temperature and humidity of the library and the installation of metal storage units for the manuscripts. At the close of the project, all manuscripts will have been fully inventoried, photographed, and stored in acid-free archival boxes and folders before being returned to the family. Copies of the images will be provided to the family library, to the British Library, and to the local archival partner in Jerba.

Concurrently with the photographing of the El Bessi collection, our project has been documenting the existence of other private manuscript collections in Jerba. This includes archival-based research as well as on-site discussions and interviews with families from across the island. The aim is in part to document the existence of libraries for a future, expanded iteration of the project as well as to increase awareness about what we are doing and why.

Following the project's conclusion in early 2018, we will be holding a public exhibition of the project outcomes. This will include a photograph exhibition, public lectures on the collection and its history, as well as an invitation for other families to contact us about the possibility of photographing their collections. The purpose will be to encourage other families to participate in a larger preservation effort in the future. Dozens of private 


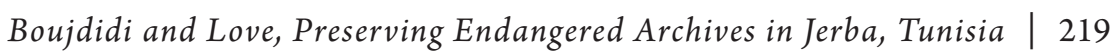

manuscript libraries exist on the island, and all are in danger of being lost to humidity and pest damage. Aware of these threats, families are nevertheless often reluctant to allow outsiders access to them. Our hope is that through these outreach efforts, we can help educate the public on the value and merits of preserving and sharing their collections and expand our project significantly in the coming years. 